\title{
A Continuous Series of Outreach Programs to Recruit Young Women to Engineering
}

\author{
Elizabeth DeBartolo and Margaret Bailey
}

Mechanical Engineering Department, Rochester Institute of Technology

\begin{abstract}
The Rochester Institute of Technology's Women Engineering program (WE@RIT) has developed a continuous series of outreach programs for young women in grades 6-12. The sequence has been developed partly to help recruit more women applicants to RIT's predominantly male student body and partly in response to parent requests for more programs for their daughters. Events include Park and Ride, a $6^{\text {th }}$ and $7^{\text {th }}$ grade amusement park design program; Expanding Your Horizons, an $8^{\text {th }}-10^{\text {th }}$ grade engineering and science conference; the SWE Sleepover, an introduction to Engineering at RIT for $11^{\text {th }}$ grade women; Colleges and Careers, a summer recruiting workshop for $12^{\text {th }}$ graders; and I Built My Computer @ RIT, a summer camp for $1^{\text {st }}$ year women engineering students accepted to RIT. An overview of all five programs is presented here, but the focus of this paper will be the Park \& Ride and Expanding Your Horizons workshops, which are new as of 2004.
\end{abstract}

Background and Motivation

Increasing the diversity among those who graduate with engineering degrees is essential for providing a strong workforce for the nation's high technology industries. In particular, women comprise $50 \%$ of the population, but fewer than $20 \%$ choose to major in subjects such as computer, electrical and mechanical engineering. NSF recently reported that, while the number of women enrolling as freshmen in full-time engineering programs increased by nearly 2,000 from 1994-2002, the percentage of female freshmen engineering students dropped from $19.4 \%$ to $17.2 \%{ }^{1}$.

At RIT, the percentage of women engineering students graduating each year from the Kate Gleason College of Engineering is approximately 11\%, significantly below the 2003 national average of $20.4 \%{ }^{2}$. However, unlike the national trends in engineering student attrition, the overall retention rate for this relatively small group of RIT engineering women is actually higher than the retention rates associated with their majority male peers, although both groups fall below RIT's long-term student retention goals. Our demonstrated ability to keep women here once they decide to come indicates that RIT is an excellent place to work at bringing more women into engineering. 
Women faculty from across RIT's college of engineering have begun to address both of these problems by developing outreach programs to help encourage young women to pursue an engineering education, and in particular, to do so at RIT. At the present time, five programs are in place, with a target audience ranging from $6^{\text {th }}$ grade girls to $12^{\text {th }}$ graders preparing to matriculate at RIT. The programs are staggered throughout the year, to reduce the load on the RIT student volunteers and faculty who participate (Table 1).WE@RIT's objective is to make a continuous series of outreach programs available as the girls proceed through their pre-college years.

Table 1: Timing of program offerings by WE@RIT.

\begin{tabular}{|c|c|c|}
\hline Quarter & Program & Target Audience \\
\hline $\begin{array}{c}\text { Fall } \\
\text { (October) }\end{array}$ & $\begin{array}{c}\text { Expanding Your Horizons } \\
\text { Conference }\end{array}$ & $8^{\text {th }}-10^{\text {th }}$ grade \\
$\begin{array}{c}\text { Winter } \\
\text { (December) }\end{array}$ & Park and Ride Workshop & $6^{\text {th }}-7^{\text {th }}$ grade \\
\hline $\begin{array}{c}\text { Spring } \\
\text { (March) }\end{array}$ & SWE Sleepover & $11^{\text {th }}$ grade \\
\hline $\begin{array}{c}\text { Summer } \\
\text { (July, August) }\end{array}$ & Colleges and Careers Day & rising $12^{\text {th }}$ graders \\
\hline $\begin{array}{c}\text { Summer } \\
\text { (July) }\end{array}$ & I Built My Computer@RIT & women entering RIT \\
\hline
\end{tabular}

Summary of Existing Outreach Programs

Prior to 2004, there were three opportunities for girls in $11^{\text {th }}$ and $12^{\text {th }}$ grade to come onto the RIT campus and learn about engineering at the institute. These three programs have been held primarily as recruitment/retention tools for RIT and are discussed below

\section{$\underline{\text { SWE Sleepover }}$}

The SWE (Society of Women) Sleepover is an annual program, held each spring, for $11^{\text {th }}$ grade women. The program has been in existence for a number of years, and is planned and run almost entirely by RIT's Society of Women Engineers student section. Since it is mainly used as a recruitment tool to demonstrate RIT's engineering programs to young women in high schools around the Northeast, it is centered around providing an RIT experience. Attendees spend a full day on campus, where they participate in a series of laboratory activities provided by students and faculty in the departments of Electrical, Industrial and Systems, Mechanical, and Microelectronics Engineering. The young women also spend the night on campus with RIT students. Attendance has grown in recent years, and RIT hosted over 40 girls for the 2004 SWE Sleepover.

\section{Colleges and Careers Day}

Colleges and Careers Day is an annual summer event targeting high school students between their $11^{\text {th }}$ and $12^{\text {th }}$ grade years. It is an institute-wide recruitment event designed for male and female students. Students interested in engineering are able to participate in hands-on activities in addition to learning about the application and financial aid processes. 


\section{Built My Computer@, RIT}

The summer workshop is a three-day residential event using the construction of a personal computer as the central theme. Aspects of all five of the college of engineering disciplines (Computer, Electrical, Industrial and Systems, Mechanical, and Microelectronics Engineering) are highlighted during the program. The students are placed into teams of two, and each team is given computer components for two personal computers (PC's). During the program, the teams are instructed on how to build a computer. Current RIT women engineering students who were past program participants serve as laboratory assistants during I Built My Computer each year, providing not only instruction and advice, but also serving as role models. At the conclusion of the workshop, the participants have a fully functional PC which they take home and later in the summer bring back with them as incoming first year engineering students. In addition to building the computers, the students receive instruction on the nature and function of all computer components, the manner in which these components come together as a system, and how the computer is used in engineering laboratories.

In addition to the technical sessions of the three-day summer program, the participants stay in the residence halls on campus and participate in extracurricular activities with each other as well as volunteer RIT undergraduate students. Past activities have included a trip to a local amusement park, teambuilding activities in RIT's Interactive Adventures facility, shopping trips, and going to the movies. This gives incoming engineering women an early chance to feel like they are part of a community at RIT, thus assisting them in their transition from high school to college. While this aspect of the program does not contribute to the young women's technical education, their personal development is just as important to their success in an engineering program.

Past participants have raved about the program. Comments from several participants indicated that attending the summer program removed the anxiety associated with going to college. They had already made new friends, knew their way around campus, had met key faculty and staff, and knew what to expect when they returned in September. On the workshop evaluation, students wrote comments such as, "I really loved doing this camp! I feel a lot more comfortable with RIT now," and, "I thought this program was a wonderful opportunity."

\section{New Outreach Programs for 2004}

New for 2004, WE@RIT has developed two new programs: Park and Ride for $6^{\text {th }}$ and $7^{\text {th }}$ grade girls and Expanding Your Horizons (EYH) for $8^{\text {th }}-10^{\text {th }}$ grade girls. Park and Ride has been offered twice to date (April 2004 and December 2004) and EYH once (October 2004). This section describes efforts to publicize and recruit for the new events as well as descriptions of the actual events themselves.

\section{Development, Recruitment, and Application Processes}

Most of the initial planning for the two new events was done with the help of a RIT co-op student. RIT's engineering and engineering technology students are required to complete 48 weeks of co-op experience prior to graduation, and one of these students, who was already active in the women in engineering programs at RIT, was hired to work on these two projects full-time. While the student worked closely with faculty members on many of the ideas for the programs, 
the co-op student independently took care of many of the logistical details, such as planning meals, coordinating student volunteers, and ordering supplies. While the assignment is a very non-traditional co-op experience for an engineering or technology student, the student was able to exercise many leadership skills that most students would never see on a first co-op assignment: communication, event planning, budgeting, and managing volunteers, all for a technical event.

Recruitment for Park and Ride and EYH was done through school guidance counselors as well as math and science teachers. Brochures were sent to schools both in the city of Rochester and the surrounding towns; where possible, they were sent directly to a faculty or staff member with whom contact had previously been made. In addition, the local Girl Scout Council and Society of Women Engineers Rochester area professional section were notified and included information about the event(s) in their newsletters. The target group size is 30 girls for Park and Ride and 80 for $\mathrm{EYH}$.

Both new events included a formal application process. In each case, applicants were required to complete a short application, write a brief (one-page) essay describing why they wanted to participate, and pay an application fee - $\$ 75$ for Park and Ride and $\$ 20$ for EYH. For students with demonstrated need, defined as eligibility for free school lunches, the application fee was waived. Application fees serve two purposes: first, they help offset the costs of meals, supplies and paying student workers to help with the planning; second, they ensure that the applicants had some vested interest in following through with attendance. Park and Ride received 15 applicants for its first offering in the spring of 2004 and 26 for its second offering in the winter of 2004. For both cases, one applicant was not accepted due to an incomplete application packet. EYH received 23 applications, and all girls were accepted. Both programs are operating in a deficit mode due to the high costs of initial planning and purchase of durable equipment.

Park and Ride - An Amusement Park Design Workshop for Middle School Girls Park and Ride is a three-day event for $6^{\text {th }}$ and $7^{\text {th }}$ grade girls interested in science and engineering. The girls are at the critical age where they can choose to follow an education path that will enable them to pursue a technical college degree. The theme for the program is amusement park design, and the engineering activities programmed for participants center around constructing and programming Lego Mindstorms robots for a final competition. While a number of other outreach programs nationwide incorporate robotics and Lego Mindstorms ${ }^{3-6}$, they are straightforward to use but have a high impact on the students who learn to use them. An important part of the Park and Ride program is also a discussion of different branches of engineering and how each field fits into a functioning amusement park. The girls interact extensively with volunteer engineering undergraduate students as well as engineering faculty. The program also provides sessions on the last day for parents to learn more about engineering and watch their daughters' robots compete.

The culmination of the three-day event is a competition for which the participants design and build Lego-based robots. The theme of the competition is to design an amusement park ride cart that will drive passengers through a predetermined ride track. The object is to have the passengers see the most "attractions" inside the ride in the shortest amount of time. The robot 
carts are required to be autonomous, but the girls are allowed to nudge their robots within certain guidelines in exchange for a point penalty.

The object of Day 1 of Park and Ride is to get the participants familiar with the Lego Mindstorm kits and with each other. The welcome address has been given by a faculty member who talks to the girls about engineering and design in general. For the April and December offerings, the girls were welcomed by Kevin Kochersberger, an RIT professor who was the pilot for the Wright Brothers Centennial celebration in 2003. After the welcome address, some time is designated for icebreaker activities. The girls learn each other's names and get to know one another before being paired up for the rest of the event's activities. The rest of the morning session is left for construction of a Lego-supplied amusement park ride. The rides are fairly complex, but instructions are provided with the kits and the rides can be completed in less than two hours. As the girls build, RIT student volunteers circulate and help groups with questions and offer helpful hints. After a lunch break, the afternoon session is reserved for learning how to program the Lego kits. Again, RIT student volunteers circulate and provide help where needed. The day closes with presentation of the design problem for the final competition and a discussion of the engineering reasons behind the contest. The amusement park management wants to move riders through quickly, so they reduce long lines and keep the patrons happy, as well as being able to handle more paying park visitors. However, they also want each rider to see as much as possible, so they feel that they have gotten their money's worth out of the visit.

Day 2 of Park and Ride is almost entirely devoted to having the girls design, build, and program their own Lego robots for the Day 3 competition. Two copies of the competition track are available for the girls to use for testing prior to the actual contest. Several breaks, including lunch are provided for the girls. At the end of the day, the girls break early from their construction to listen to a speaker from Disney. RIT's Industrial and Systems Engineering department is fortunate to have a graduate who works for Disneyworld in Orlando, and who is willing to travel to Rochester to talk to the girls at the workshop. She talks with the girls about her experiences as an engineer and the sorts of jobs that engineers can hold at Disney. This helps to take the emphasis off of the robotics aspect of the workshop and encourages the girls to think about all the different types of engineers that have to work together to make the park run.

Day 3 of Park and Ride is a half-day for both parents and participants. While the girls make the final adjustments on their robot carts, the parents are invited to a panel discussion with RIT faculty, students, and at least one engineer from industry (including the Disney speaker). The parents and girls all get together again for the competition and final awards ceremony. Each participant receives a certificate of completion, and an effort is made to recognize each team of girls for some special aspect of their experience: teamwork, sportsmanship, aesthetics, or robustness.

Finally, since the Park and Ride event targets girls in both $6^{\text {th }}$ and $7^{\text {th }}$ grade, it is important to note that the scope of the design competition can easily be changed from year to year so that it still incorporates the Lego Mindstorms, but requires different skills of the girls. This means that girls can return for both of the years in which they are eligible and still gain something new each time. 


\section{Expanding Your Horizons}

Expanding Your Horizons is part of a nationwide conference series ${ }^{7}$ designed to encourage young women to pursue careers in science and engineering. The RIT conference, an all-day Saturday workshop, is in its first year. The workshop includes two tracks: one for students and one for parents. The student track is for $8^{\text {th }}-10^{\text {th }}$ grade women, who participate in four different activities designed to teach them about different fields of engineering and science: Robotics, Aeronautical/Industrial Engineering, Materials, and Civil Engineering Technology. Broken up into two groups, the attendees spend about an hour in each of the activities. The parent track includes informative sessions on the history of engineering, tips for helping their daughters to succeed in math and science, a tour of the engineering facilities, and a panel discussion with engineering faculty, students, and professionals. Parents are also given the opportunity to participate, separate from the young women, in some of the activities their daughters had tried. As with the Park \& Ride, there is an emphasis on interaction with college students and faculty members for both parents and students.

The four engineering activities offered were:

- Robotics - The attendees are able to build some simple Lego models and control them, both by using pre-written programs and by modifying the existing programs to see what changes occurred.

- Aeronautics/Industrial Engineering - After a brief discussion on the history and science of flight, the attendees constructed paper airplanes for a flight competition. Students also learned about aspects of reliability, repeatability, and some aspects of probability.

- Materials Science - Attendees watch polymer crystals absorb water as they discussed properties of polymers and different applications of the different materials. They experiment with polyester fleece, Elmer's Glue, and commercially available soil additive for water retention.

- Civil Engineering - After hearing about career opportunities in Civil Engineering, attendees use survey equipment, bridge simulation software and test concrete cylinders to failure.

As with the Park and Ride, EYH is targeted at a range of ages, and RIT does not want to lose attendees just because "I've already done this". The specific activities are not important, as long as they convey the breadth of career options available in science and engineering. This means that young women who choose to return for each of their $8^{\text {th }}, 9^{\text {th }}$, and $10^{\text {th }}$ grade years will be able to see different activities even though they are attending the same program.

Since EYH has only just finished its first iteration, improvements will be made starting with the 2005 conference. All 12 parents who completed post-even surveys indicated that they would send their daughters back next year if different activities were offered. Seven out of 12 parents indicated on post-event surveys that they would also attend the parent sessions again next year if the programs offered were different; the remaining five indicated that they might attend.

Some interesting observations were made from the participant surveys. Girls were surveyed at the start of the event, and again at the end of the day. While some questions focused on either the girls' backgrounds (pre-event) or their impressions of the event (post-event), other questions regarding their impressions of engineers and engineering were asked both before and after to 
assess whether or how much the program affected their views. Table 2 contains the highlights of the pre- and post-event surveys.

Table 2: Selected before-and-after survey results from EYH.

\begin{tabular}{|c|c|c|c|}
\hline Question & Response & $\begin{array}{l}\text { \# Before } \\
\text { (19 total) }\end{array}$ & $\begin{array}{c}\text { \# After } \\
\text { (21 total) }\end{array}$ \\
\hline $\begin{array}{l}\text { Please write a brief definition } \\
\text { or draw what you think an } \\
\text { engineer is or does }\end{array}$ & $\begin{array}{l}\text { Designs/builds/creates } \\
\text { Solve problems/improve things } \\
\text { Works with machines/machinery } \\
\text { (Several others with just one } \\
\text { response) }\end{array}$ & $\begin{array}{l}9 \\
7 \\
4\end{array}$ & $\begin{array}{c}12 \\
14 \\
1\end{array}$ \\
\hline $\begin{array}{l}\text { Name some things that } \\
\text { engineers create } \\
\text { (only most common responses } \\
\text { and responses that were present } \\
\text { on only one survey are } \\
\text { included) }\end{array}$ & $\begin{array}{l}\text { Cars } \\
\text { Bridges } \\
\text { Machinery } \\
\text { Structures/buildings } \\
\text { Computers/software } \\
\text { Planes } \\
\text { Everything/all man-made things } \\
\text { Robots } \\
\text { Lawn Mower } \\
\text { Lenses } \\
\text { Chain saw } \\
\text { Missiles } \\
\text { Movies } \\
\text { Lip gloss } \\
\text { Soap } \\
\text { Plants/plant food } \\
\text { Shopping carts } \\
\text { Infrastructure } \\
\text { Materials } \\
\text { Space station }\end{array}$ & $\begin{array}{l}10 \\
9 \\
7 \\
6 \\
6 \\
5 \\
1 \\
3 \\
2 \\
1 \\
1 \\
1 \\
0 \\
0 \\
0 \\
0 \\
0 \\
0 \\
0 \\
0\end{array}$ & $\begin{array}{l}9 \\
4 \\
4 \\
5 \\
4 \\
7 \\
6 \\
0 \\
0 \\
0 \\
0 \\
0 \\
2 \\
2 \\
2 \\
2 \\
1 \\
1 \\
1 \\
1\end{array}$ \\
\hline
\end{tabular}

There are two striking differences in the pre- and post-event surveys. The first is in the number of participants who think an engineer solves problems. Before attending EYH, less than half of the participants (7/19) gave these responses, but afterward twice as many (14/21) girls gave these as descriptions of what engineers do. The second observation is in the breadth of things the girls think engineers create. Dominating the list before and after were the traditional cars, planes, structures, bridges, and machinery. Before the event, some girls added ideas like robots, lawn mowers, chain saws, and missiles - all very mechanically-oriented devices. After the event, however, things like movies, soap, and lip gloss appeared. Six girls even indicated that 
engineers designed "everything not made in nature" (compared with one girl before the conference). The surveys indicate that, at least in the short term, the event did expand the participants' perceptions of what engineers can do.

\section{Lessons Learned}

A number of important lessons have been learned in the development of Park and Ride and EYH. In addition to finding much truth in a comprehensive list of suggestions offered by Pierson ${ }^{4}$, the following insights are from the experiences at RIT:

- RIT student volunteers are extremely popular with participants. They are an important part of all of RIT's outreach activities, and the attendees seem uniformly thrilled to be hanging around with college students.

- Timing the outreach events is important - local school schedules must be considered, as well as RIT student schedules (e.g., don't plan an event too close to an RIT break when student workloads are high).

- Parents have provided some valuable suggestions for spreading the word about future activities. One parent, who home-schools her daughter, provided us with contact information for an area home-school email newsletter; others asked that we send information about future events directly to them to spread the news to other parents, in addition to going through schools.

- Require parents to state clearly who will be picking up their daughter, or if the daughter is to be allowed to take public transportation home at the end of the day.

- Creating a program that includes "down time" for the participants is essential. During this time, participants have an opportunity to meet their peers from other schools and mingle with college students.

- Including icebreaker events early in the program is a great way to ease the participant's anxieties about being in an engineering building on a college campus.

- If the weather permits, incorporating outside, fun activities into the program are an excellent way for these young women to bond in a different setting.

- Rather than catering a lunch within the event area, take the young women to one of the campus eateries and provide them with a food voucher. The participants consistently list their lunch experiences as one of their favorite activities within the various programs.

- Involve the participants in as much hands-on activities as possible. Eliminate lecture-type discussions and replace with highly interactive exchanges between the young women and session facilitators.

Future Plans

Plans for the future include both improving the existing outreach programs and creating new ones. Now that the existing programs have all been run at least once, our participant surveys can start to shift focus from the "what did you think of the program?" and "how can we improve this?" questions that help WE@RIT to plan events to the "what did you know about engineering when you came here?" and "what did you learn?" questions that help the students reflect on what they've gained. One that may be helpful is based on the Draw an Engineer Test described by 
Knight and Cunningham ${ }^{8}$. A before and after "test" can be administered to see if the attendees' perception of what an engineer is/does has been changed by what they just learned. Reflection activities like these can be valuable in helping RIT's programs make a lasting impact on the participants.

Long-term future plans include developing additional programs, both to target new age groups and to provide additional opportunities to middle and high school aged girls. Responses from parents of attendees indicate that there is an interest in this sort of activity in the Rochester area, with nearly all of the attendees and parents saying that they would come back to RIT for other workshops like these. Most parents expressed interest in summer camps, both day and overnight, from just a few days to a full week.

Finally, with a continuous series of programs, WE@RIT can begin to track attendees from year to year as they attend different programs at RIT. Longitudinal tracking of attendees can be difficult, but if girls who are interested from the first program are invited back year after year for different programs, tracking may become easier.

References

[1] National Science Foundation Women, Minorities, and Persons with Disabilities in Science and Engineering 2004 Report.

[2] American Society of Engineering Education 2003 Profiles of Engineering and Engineering Technology Colleges.

[3] Reamer, Sharon M. and Safai, Nick M., "Promoting Science and Engineering in Grades K-12 by Means of a Summer Workshop - A Universal Model", Proceedings, 2004 ASEE Annual Conference \& Exposition, Salt Lake City, June 2004.

[4] Pierson, William E., Dulin, Betsy, and Robinson, Michael , "Growing the Pool of Engineers - Experiences in Hands-On Learning at a Summer Academy", Proceedings, 2002 ASEE Annual Conference \& Exposition, Montreal, Canada, June 2002.

[5] Nagchaudhuri, Abhijit and Singh, Gurbax, "Middle-School Students Get Introduced to Engineering at UMESNOAA Summer Camp", Proceedings, 2003 ASEE Annual Conference \& Exposition, Nashville, June 2003.

[6] Avanzato, Robert, "Mobile Robot Navigation Contest for Undergraduate Design and K-12 Outreach", Proceedings, 2003 ASEE Annual Conference \& Exposition, Nashville, June 2003.

[7] Refer to http://www.expandingyourhorizons.org for more information.

[8] Knight, Meredith and Cunningham, Christine, "Draw an Engineer Test (DAET): Development of a Tool to Investigate Students' Ideas About Engineers and Engineering”, Proceedings, 2004 ASEE Annual Conference and Exposition, Salt Lake City, June 2004.

\section{Biographical Information}

ELIZABETH A. DeBARTOLO is an Assistant Professor in the Mechanical Engineering Department at RIT. She earned her BSE at Duke University in 1994 and her MSME and Ph.D. at Purdue University in 1996 and 2000, respectively. She works with several students on predicting and enhancing fatigue life in aircraft materials and structures and is active in the college's outreach programs. 
MARGARET BAILEY, registered professional engineer, is the Kate Gleason Chair and Associate Professor in Mechanical Engineering at RIT. She earned her BSE at Pennsylvania State University in 1988 and her Ph.D. at University of Colorado at Boulder in 1998. She conducts research with students on exergetic analysis and neural network modeling of energy consumption in complex mechanical systems. Dr. Bailey is very active in the creation and guidance of RIT's Women in Engineering program. 